\title{
A Strategic Model for a Northeast Asian Logistic Hub in Korea
}

\begin{abstract}
Hun-Koo Ha*
The objective of this study is to present a successful strategy to promote Korea as the logistics hub of Northeast Asia. Firstly, we introduce the necessity of a logistic hub strategy for Korea. In order to develop a successful strategy, we consider the 'free trade zone' model of the Netherlands and China. We develop a realistic and suitable model for Korea based on this 'free trade zone' model. Our proposal for a successful logistic hub strategy for Korea is the fulfillment of the following six objectives: 1) security of market accessibility, 2) improvement of the logistic system, 3) improvement of the education system, 4) improvement of the tax system, 5) assurance of labor market flexibility, and 6) development of an appealing living environment for foreigners.
\end{abstract}

\section{I. 머리 말}

세계경제는 미국주도의 시장중심 경제체제(WTO)로 전환되는 한편 지역경제블록화 현상(regional cooperation)도 심화되고 있다. 이러한 가운데 동북아 경제권은 중국경제의 급부상 등으로 세계경제에서 의 비중 증대 및 역내 교역과 경제협력이 가속화되고 있는 추세에 있다. 이에 따라 세계경제에서 현재 $20 \%$ 수준인 동북아 경제권의 비중은 향후 20 년 이내 $30 \%$ 수준으로 성장할 전망이라고 한다. 이러한 상황에서 중국경제의 급부상은 한국경제에 기회이자 위협요인이 되고 있는 것으로 이야기되어 진다. 이는 중장기적 으로 우리나라의 수출주도 및 제조업중심의 발전전략은 한계에 다다를 것이라는 잠재적 위기의식이 상존 하고 있는 데다 한국경제를 떠받쳐온 제조업 경쟁력은 조만간 중국에 밀리게 될 것이며 그렇다고 서비스업 이 받쳐주지도 못하는 상황이어서 한국경제는 앞으로 내리막길을 걸을 수 밖에 없다는 지적(오마에 겐이 찌, "02.1)과 일본 - 중국이라는 호두까기(Nutcracker)사이에 끼인 호두의 운명이라는 표현"으로 대별되 고있다.

이러한 위기의식하에서 기존의 제조업중심 발전전략을 극복하는 대안을 모색해야하며 ${ }^{2}$ 중국을 우리의 잠재적 경쟁자로 인식하는 수동적 자세에서 벗어나 중국경제 부상을 기회시장으로 활용하려는 적극적 전 략이 필요하다는 논의가 제기되기 시작하였다. 즉, 동북아 경제권의 부상에 맞춰 증가하는 물동량을 우리 나라에 유치하여 중장기적으로 우리나라를 동북아 물류중심지화로 만드는 것이 우리나라의 살길이라는 논 의가 시작된 것이다.

이러한 배경하에서 본 논문에서는 우리나라의 동북아 물류중심지화 추진을 위한 바람직한 모델을 설 정하고, 이를 바탕으로 현재 추진하고 있는 전략과의 비교 분석을 통하여 물류중심지화 전략의 성공을 위 한 추진과제를 도출· 제시하고자 한다.

*Research Fellow and Director, Center for Logistics, Transport Economics \& Northeast Asian Studies, The Korea Transport Institute, Seoul, Korea. Tel: 031) 910-3147, E-Mail: hha@koti.re.kr

"Booz-Allen \& Hamilton(1997) 참조.

2 발전대안으로 첨단산업육성, 전통산업 고부가가치화, 서비스산업 발전 등에 대한 논의가 있음 


\section{II. 동북아물류중심지화 전략의 필요성}

\section{1. 국제 물동량 전망 및 물류시스템 추이}

(1) 세계화 · 교역량 증대로 물동량 지속 증가

향후 10 년간 세계경제 성장률은 2 3\%수준으로 전망되나. 컨테이너 물동량은 $6.7 \%$ 증가할 전망이다. 1999년도의 2억TEU(1 TEU는 20피트 컨테이너 1개에 해당) 물량이 2011년에는 4.3억 TEU로 늘어날 전 망이기 때문이다. 아울러 동북아 지역은 세계 3대 교역권(EU, NAFTA, 동북아)으로 부상, 물동량 증가 세가 두드러질 전망이기도 하다. 경제성장률은 연평균 $6 ~ 7 \%$ 에 달할 것이며, 컨테이너 물동량 증가율은 연평균 $8.1 \%$ 로 예상되고 있다. 중국의 물동량은 연간 $11.5 \%$ 씩 증가하여 2011 년 67 백만TEU에 이를 전망 (동북아물동량의 $1 / 2$ 수준, 중국정부추정)이다.

〈표 1〉 컨테이너 물동량의 현황 및 전망

(단위: 백만 TEU)

\begin{tabular}{c||c|c|c|c|c}
\hline & $' 99$ & $' 00$ & $' 06$ & $' 11$ & 증가율 \\
\hline \hline 전세계(A) & 201 & 210 & 322 & 430 & $6.7 \%$ \\
\hline 동북아(B) & 54 & 59 & 97 & 137 & $8.1 \%$ \\
\hline $\mathrm{B} / \mathrm{A}$ & $25.7 \%$ & $28.1 \%$ & $30.1 \%$ & $31.9 \%$ & - \\
\hline
\end{tabular}

자료 : Ocean Shipping Consultant (1999)

\section{(2) 항공화물의 중요성 증대}

전 세계의 항공화물수요는 향후 20년간(1999년 2019년) $6.4 \%$ 의 증가를 보일 것으로 전망되고 있다. 이중 아시아 역내 항공화물 증가율은 $8.6 \%$ 로 가장 높을 것으로 전망되며, 또한 아시아 출발 - 도착화물의 비율도 크게 증가하여 아시아관련 물동량의 비율이 전체적으로 증대할 것으로 예측된다. 우리나라의 국제 화물중 항공화물은 수송물량측면에 있어서는 $0.3 \%$ 에 불과한 미미한 수준이나 수송화물의 가치측면에 있 어서는 약 $30 \%$ 를 차지하고 있다. 또한 항공화물 수송수요의 빠른 증가추세로 구성비도 높아질 전망이어 서 중요성이 더욱 커지고 있다. 대한항공의 경우 2000 년도의 국제선 수송실적은 6,357 백만톤 - 킬로미터로 서 수년간 루프트한자항공 다음의 세계 2 위를 기록하고 있다. 특히 인천공항에서의 환적비율이 높아 허브 공항으로서의 가능성을 보이고 있는데 이는 현재의 항공기로는 동남아지역에서 북미 동부지역까지 논스톱 으로 비행할 수 없기 때문이다.

〈표 2〉 국적항공사의 국제항공화물 수송 실적(김포공항, 1997년)

\begin{tabular}{c||c|c|c}
\hline 구 분 & 대한항공 & 아시아나항공 & 계 \\
\hline \hline 수 출 & $118,025(15.9 \%)$ & $51,039(25.9 \%)$ & $169,064(18.0 \%)$ \\
\hline 수 입 & $126,163(17.1 \%)$ & $54,060(27.4 \%)$ & $180,223(19.2 \%)$ \\
\hline 통과화물 & $495,813(67.0 \%)$ & $92,182(46.8 \%)$ & $587,995(62.7 \%)$ \\
\hline 계 & $740,001(100.0 \%)$ & $197,281(100.0 \%)$ & $937,282(100.0 \%)$ \\
\hline
\end{tabular}

자료 : 교통개발연구원, 인천국제공항의 항공화물부문 허브화를 위한 정책방향 (1998) 
(3) 해공복합(Sea \& Air)화물운송의 증대

중국발 해공복합화물 운송 물동량은 1992-1994년 기간중에는 연평균 $50 \%$ 이상의 신장세를 보였으며 이후에도 계속 $10 \%$ 대의 성장률을 기록하여 2010 년에는 18 만톤에 이를 것으로 전망되고 있다. 1997 년 이후 의 경기여파로 1999 년 4,222 톤, 2000 년에는 3,545 톤으로 잠시 위축되었으나. 중국경제의 신장 등에 의해 꾸 준히 증대할 것으로 예상된다.

〈표 3〉우리나라 경유 중국발 해공복합운송량 추이 및 전망

(단위: 천톤)

\begin{tabular}{c||c|c|c|c|c|c|c}
\hline 연 도 & 1992 & 1993 & 1994 & 1996 & 2000 & 2005 & 2010 \\
\hline \hline 운송량 & 2.0 & 8.5 & 12.5 & 19.0 & 60.0 & 120.0 & 180.0 \\
\hline
\end{tabular}

자료 : 대한항공 (1997)

(4) 운송수단의 대형화 및 Hub \& Spoke 시스템 구축

대형 컨테이너선 및 화물전용기 취항 증가는 규모의 경제면에서 유리하다. 1980 년대의 $3,000 \mathrm{TEU}$ 급 컨테이너선이 90년대에는 5,000TEU급으로, 2000년대에 들어선 이후 8,000TEU급까지 계획되고 있기 때문 이다. 이러한 선박이나 항공기의 대형화는 또 비용절감 - 수송시간 단축을 위해 소수 거점 공항 - 항만에만 기항하고, 주변지역은 지선편(Feeder)서비스 또는 내륙수송으로 대응하는 형태로 발전하고 있어 허브항 만 · 공항 육성을 위한 각국간의 경쟁이 심화되고 있는 실정이다.

\section{2. 물류산업의 변화 전망}

(1) 기업활동 세계화에 따른 물류관리의 중요성 증대

WTO로 특징지어지는 투자 - 무역의 자유화, 정보통신기술 및 교통인프라의 발전에 따라 생산?유통 등 기업활동이 세계화되고 있다. 이들 세계화 기업은 원자재와 부품을 2 개국 이상에서 조달하고 지리적으 로 격리된 2 개국 이상의 공장에서 제조/조립하여 전 세계시장에 공급하고 있다. 세계화기업은 이처럼 표 준화된 글로발 생산시스템의 이점을 향유하면서 재고관리단계에서는 현지 시장별로 상이한 고객수요에 대 응하고 있다. 이들은 표준화를 통한 규모의 경제 실현을 목표로 시장마다 경제환경, 사회문화적 가치 - 행 동기준, 소비자관습 - 기대수준이 다름에 부응하고 있는 것이다. 이는 곧 범세계적 공급사슬관리(Supply Chain Management)의 중요성의 부각이라는 결과를 낳게 되었다.

재고의 집중화와 연기전략(Delayed configuration)을 세계화 기업들의 대표적인 전략의 하나로 들 수 있는데 이는 중앙집중형 유통체계를 통해 전체적인 재고를 최소화하는 전략이며, 공통적인 생산단위 (Module)을 사용하고, 최종조립은 소비자의 요구사항이 파악되는 최종시점까지 연기하는 전략을 의미한 다. 아울러 과거 국가별 다극분산형 물류센터를 지역거점단위 중앙집중형 물류센터로 통합하고 있는데, 물류센터에서는 재고관리 외에도 부가가치 물류활동(조립, 혼합, 부품추가, 상표부착, 품질검사, 재포장 등)을 수행하고 있다. 이러한 전략이 싱가폴, 네덜란드 등 지역거점 물류기지의 성공 배경이라고 할 수 있 다. 


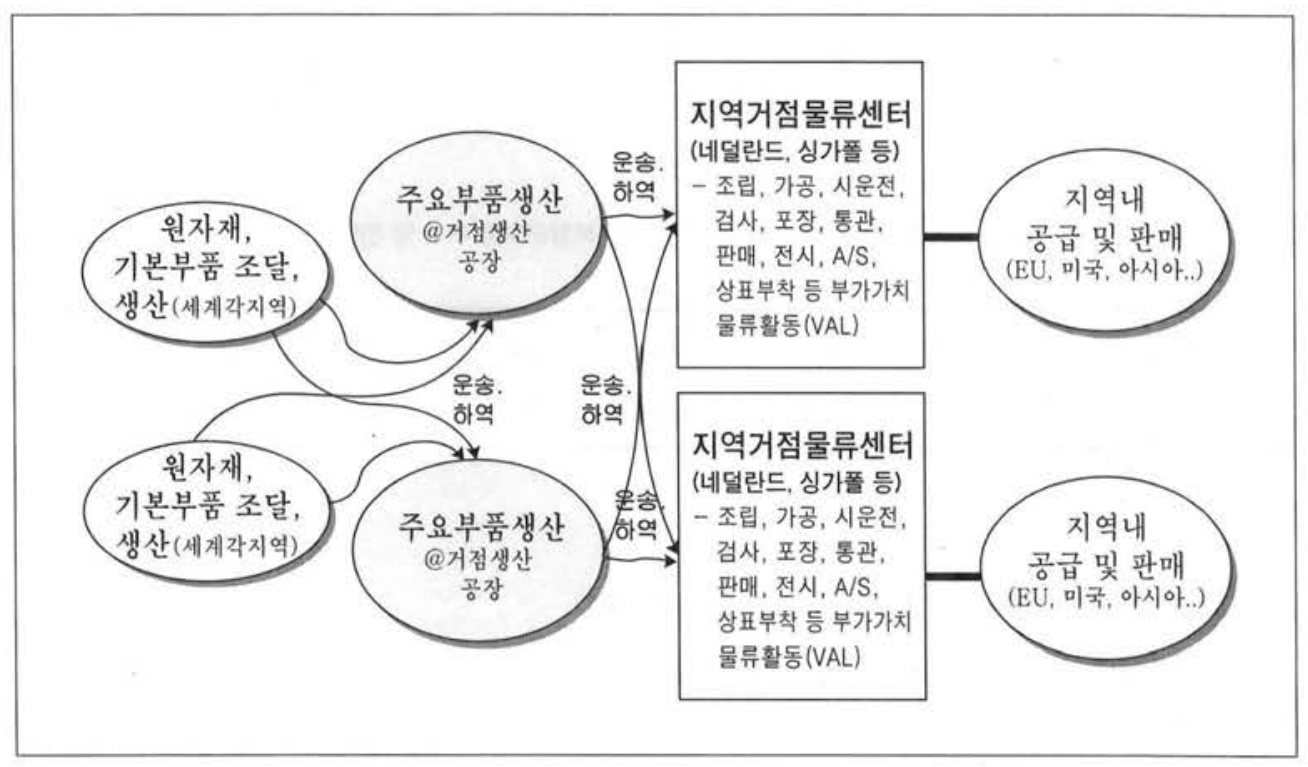

\section{(2) 기업물류관리체계의 고도화}

정보통신기술의 발달, 경영자원관리기법 첨단화 등으로 물류관리체계의 고도화가 이루어지고 있다. 공급사슬관리(SCM: Supply Chain Management)는 원자재조달에서 소비자에 대한 상품전달까지의 원 자재 흐름, 재고관리, 관련정보의 흐름 등 전과정을 계획, 집행, 관리하는 과정이며, 적기배송(JIT: Just In Time)은 필요로 하는 원자재, 부품, 상품을 정확한 시간, 정확한 위치에 인도할 수 있도록 관리하는 것으로 재고 최소화, 리드타임단축 등을 통해 비효율요인 제거에 목적을 두고 있다. 미국·유럽·싱가폴 등 물류 선진국은 물류관리에 있어 정보화의 장점을 감안하여 국가차원에서 물류정보화를 추진중이며, 개별기업 차원에서도 첨단 정보통신기술을 활용하여 실시간으로 물류흐름을 관리하는 노력이 지속되고 있다.

(3) 아웃소싱(Outsourcing) 및 물류전문업체의 성장

선진국기업들은 물류업체와의 전략적 제휴 등을 통해 물류활동을 아웃소싱하고 있는데 이는 물류외의 핵심역량에 집중함으로써 경영효율성을 제고하기 위한 것으로 포춘지(Fortune)선정 500 대 기업 중 전문 물류업체 이용비율은 1995 년의 $65 \%$ 에서 2000 년에는 $77 \%$ 에 이르고 있다. 우리나라의 경우 주요기업의 물 류외주비율은 $16.9 \%$ 수준 ${ }^{3}$ 이며, 수출입업체의 경우 $25.7 \%$ 가 제 3 자물류를 활용"하고 있는 것으로 나타났 다. 이로 인해 물류기능에 특화한 전문물류업체(3PL, Third Party Logistics)들이 발전하고 있다.

3) 대한상공회의소(2002)

9 한국무역협회(2002) 


\section{3. 물류중심지의 개념 및 발전 유형}

(1) 물류중심지의 개념

물류중심지란 일정한 지역에서 세계 여러 지역경제권들을 연결하는 글로벌물류(global logistics)시 스템에서 동북아 지역경제권의 주변지역에 물류 - 정보 통신 관련 서비스를 제공하는 기지로 정의될 수 있 다. 이러한 물류중심지의 목표는 외국의 자본과 기업 및 기술을 직접투자(FDI)의 형태로 유치함으로써 그 지역의 경제성장 잠재력을 극대화하고자 하는 데에 있다.

이러한 목표를 달성하기 위해서는 다국적 기업(MNCs)들의 지역 물류센터(Distribution Center), 지 역본부(Head Quarter), 콜센터(Call Center) 등을 유치하는 것이 최첩경이라 할 수 있다.

(2) 물류중심지의 발전 유형

이같은 일정한 지역내의 물류중심지는 다음과 같은 4 가지의 유형으로 나타나는데, 각 국은 지리적 - 경 제적 여건과 특성에 맞는 중심지를 목표로 전략을 추진하고 있는데, 궁극적으로 복합중심지로의 발전을 목 표로 하고 있다. 우리나라에서도 이러한 목표를 가지고 관세자유지역, 자유무역지역, 국제자유도시 등을 추진하고 있다.

〈표 4〉 지역내 중심지의 발전 유형

\begin{tabular}{|c|c|c|c|c|}
\hline 구 분 & $\begin{array}{c}\text { 생산의 중심지 } \\
\text { (export } \\
\text { processing(1)) }\end{array}$ & $\begin{array}{c}\text { 교역·물류의 중심지 } \\
\text { (Warehousing(2)+ } \\
\text { logistics(3)) }\end{array}$ & $\begin{array}{c}\text { 금융의 중심지 } \\
\text { (offshore } \\
\text { banking(4)) }\end{array}$ & $\begin{array}{c}\text { 복합기능의 중심지 } \\
(1)+(2)+(3)+(4))\end{array}$ \\
\hline 중계운송 & & $\circ$ & & 0 \\
\hline 창고· 보관 & & 0 & & $\circ$ \\
\hline 제조 & $\circ$ & & & 0 \\
\hline 연구개발 & & & & $\circ$ \\
\hline 국제금융 & & 0 & & 0 \\
\hline 국제업무, 무역 & & 0 & 0 & 0 \\
\hline 관광·레저 & & $\circ$ & & 0 \\
\hline 사례 & 수출자유지역 & $\begin{array}{l}\text { 자유무역지역 } \\
\text { 관세자유지역 }\end{array}$ & 역외금융센터 & $\begin{array}{c}\text { (물류· 비즈니스 중심지) } \\
\text { 국제자유도시 }\end{array}$ \\
\hline
\end{tabular}

자료 : 교통개발연구원 (2002)에서 재인용.

\section{4. 한국의 물류중심지화 필요성}

(1)동북아 국가들의 물류중심지화를 위한 노력

가. 공항과 항만 등 물류인프라시설의 대대적 확충

동북아 경제권의 부상에 맞춰 증가하는 물동량 - 비즈니스 수요를 선점하기 위한 동북아 주변국간 경 쟁이 가속화되고 있다. 컨테이너 물동량 증대에 대비하여 항만시설의 확충을 대대적으로 수행하고 있는 데, 중국의 경우 10 년내 현 시설의 2 배 수준 확충을 계획하는 등 물류중심지화를 추진하고 있고, WTO 가 입 등 향후 자체 물동량 증가에 대비하여 상해항을 세계 최대 항만으로 건설할 계획을 추진하고 있다. 상해 항은 현재 부산항과 같은 규모인 18선석을 운용중이나 2011년까지 상해항 인근 대소양산군도(大小洋山群 島)를 개발, 58 선석을 추가적으로 확충할 예정이다. 
〈표 5〉 동아시아 주요 항만의 컨테이너 선석 규모

(단위: 선석)

\begin{tabular}{c||c|c|c|c|c|c|c}
\hline & 홍 콩 & 싱가폴 & 카오슝 & 고 베 & 부 산 & 광 양 & 상 해 \\
\hline \hline 현석석수('01) & 26 & 37 & 27 & 37 & 21 & 7 & 18 \\
\hline 확충계획('11) & 23 & 39 & 23 & 10 & 30 & 26 & 58 \\
\hline 소계 & 49 & 76 & 50 & 47 & 51 & 33 & 76 \\
\hline
\end{tabular}

자료 : 하헌구 외(2002)에서 재인용.

공항시설의 경우에도 동북아시아 허브공항을 목표로 시설확충을 진행하고 있다.

(표 6) 동북아시아 주요 공항의 규모 및 확충계획

\begin{tabular}{c||c|c|c|c|c}
\hline 구 분 & 인 천 & 간사이 & 홍 콩 & 창 이 & 푸 동 \\
\hline \hline 부 지 & 355 만평(1,435) & 155 만평(393) & 378 만평(450) & 393 만평 & 287만평(969) \\
\hline 활 주 로 & $2(4)$ & $1(3)$ & 2 & 2 & $1(4)$ \\
\hline 여객터미널 & 150 천평(338) & 91천평(183) & 166천평(270) & 153 천평 & 85 천평(240천평) \\
\hline 화물터미널 & 60천평(244) & 56천평 & 90천평(530) & 142천평 & 15 천평(121) \\
\hline
\end{tabular}

주 : 괄호안은 최종개발 완료시의 규모

자료 : 하헌구 외(2002)에서 재인용.

나. 물류중심지화를 위한 전략의 수립 및 시행

이처럼 동아시아 각국은 자국내에 세계 유수기업 등을 유치하여 경제적 파급효과를 극대화하기 위해 물류 및 비즈니스 중심지화 하려는 노력을 활발히 전개하고 있는데, 싱가폴의 경우는 1998년 "industry 21 "계획의 일부로서 물류산업발전계획(LEAP)을 추진중에 있고, 대만은 아태지역운영센터(APROC)화 전략과 2000년에 이를 수정한 Global Logistics Plan을 통하여 규제완화를 통한 물류, 통신, 반도체 등 첨 단산업, 금융 등의 동북아 중심지화를 추진하고 있으며, 일본은 2001년에 “신종합물류시책대강"을 발표하 고 물류산업의 발전을 기하기 위해 물류기본법의 제정을 논의하고 있다.

한편, 중국은 2001년에 “물류현대화 발전계획”을 마련하여 물류부문 현대화를 시도하고 있으며, 경제 특구 등을 중심으로 외국인 투자를 적극적으로 유치하여 동북아물류 및 비즈니스 중심지화 전략을 추진하 고 있다. 그러나 전반적인 물류산업의 수준은 아직 초보적인 수준을 벗어나지 못하고 있으며, 또한 상당수 의 전문가들은 중국의 성장전망에 대한 회의적인 전망 제시하면서 정치체제와 경제체제의 부조화에 따른 성장정체 가능성도 언급하고 있다. 예를 들어 일본의 물류기업인 일본통운(Nippon Express)은 중국물류 시장에 관한 보고서를 통해 중국이 경제성장과 함께 물류인프라에 있어서 빠른 개선속도를 보이고 있지만, 중국의 WTO가입으로 인한 탈 규제 움직임 등에도 불구하고, 중국이 국내물류시장의 수위를 높이는 데에 는 어느 정도의 시간이 필요할 것이라고 지적하고 있다. 또한 맥킨지(McKinsey)의 "2002 중국물류시장 보고서"에서는 중국의 민간수요는 거의 모든 품목에 걸쳐 상승세를 기록하고 있는 반면, 물품을 시장으로 운송해주는 물류시스템은 고비용에다 여전히 낙후되어 있다고 지적하고 있다. 


\section{(2) 물류중심지화 전략의 필요성}

이러한 대외적인 여건의 변화속에서 한국은 과거의 군사전략적 요충지보다는 경제활동과 국제무역의 최적지로서의 역할이 부상되고 있다. 특히, 세계 제 2 의 경제대국인 일본과 21 세기 경제대국으로 부상할 중 국 사이에 위치한 한국의 지정학적 여건 및 최근의 동아시아 경제여건은 향후 한국경제에 도전이자 기회로 작용할 것으로 보인다. 따라서 동북아 물류중심지화 전략은 동북아시아 지역에서 한국경제의 생존전략이 자 번영전략이라고 할 수 있다. 그것도 향후 5 년 이내에 선진경제 기반을 확실히 구축하지 못하는 경우 중 국과의 경쟁에서 도태될 것이라는 우려마저 제기되고 있는 실정이다. 따라서 한반도의 지정학적 이점을 활용함과 동시에 외국기업에 친화적인 환경을 조성하여 동북아지역의 물류중심지를 추구함으로써 21세기 의 한국경제의 새로운 성장엔진을 마련해야 할 필요가 있는 것이다.

\section{III. 동북아물류중심지화 전략 모델의 정립 및 한국의 여건 분석}

\section{1. 물류중심지화 전략의 대안모델 분석}

(1) 대안모델의 설정을 위한 기초분석

물류중심지화를 위해서는 다국적 물류기업의 물류센터, 지역본부, 콜센터 등을 유치하여야 하므로, 이 론적인 측면과 외국의 성공사례로부터 유치를 위한 조건을 분석할 필요가 있다.

가. 외국인 투자입지의 결정요인

Brush 등에 의하면 다국적 제조업들의 투자입지 결정요인으로 다음과 같은 것을 들고 있다. 먼저, 경 제적 요인으로 주요 시장, 핵심 고객, 핵심 공급자와의 접근성, 기타 시설과의 접근성 등이고, 사회적 - 제 도적 요인으로는 지역무역정책, 정부의 보조금, 환율 위험 등 정부의 정책, 언어, 문화, 정치적 안정성/친숙 성, 인프라 활용성 등 사회적 특성, 노동관습 및 규제, 환경 규제 등 규제의 완화 등이다.

한편 Coyle 등에 의하면 다음과 같은 요인이 투자입지결정시 고려되는 것으로 나타났다. 노동집약적 인 물류서비스 특성에 알맞는 인건비, 가용노동력, 노사관계 안정정도, 노동력의 기술수준, 생산성, 직업윤 리 등의 노동여건, 신속하고 안전한 운송가능성을 의미하는 교통시설 인프라의 활용가능성과 시장과 고객 의 접근성, 첨단산업이나 물류산업 근무자들의 쾌적한 삶의 질 제공 가능성(기후, 주택임대료, 환경, 교통 혼잡도, 교육 여건, 여가활동 등), 공급자로부터 수입하는 상품이나 서비스의 비용과 서비스 민감도를 나타 내는 공급자의 시설과의 접근성, 물류센터나 토지비용와 전기, 상하수도, 교통 등 기반시설의 이용가능성 및 비용 수준을 나타내는 토지비용 및 기반시설 등이다. 또한 UNCTAD의 World Investment Report(1999)에 의하면 다음 요인들이 입지결정요소로 작용하는 것으로 분석되고 있다.먼저, 투자정책 요 인으로 경제적 정치적 사회적 안정성과 외국인 투자에 대한 법적 - 제도적 일관성 및 국제성 그리고 무역 및 조세정책에서의 상대적 혜택 및 일관성 등이다. 둘째, 경제적 요인으로 시장규모 및 성장추이, 지역 및 세계시장에의 접근성 외 자원 및 자산 지향적 요인과 효율성 지향적 요인 등 시장지향적 요인과 투자유인 책 및 사회적 · 문화적 환경과 외부적 투자환경 등 기업환경요인이다.

아울러 O' Brien"에 의하면, 첨단산업기업 입지 선정시 고려요소는 다음과 같다. 먼저, 비용상 비교우 위로서 생산비용보다는 통관이나 전반적인 운송비용에서의 비교우위를 의미한다.

\footnotetext{
5) Brush, T et als(1999) 참조.

4) 김준동(1997)에서 재인용

n. $\mathrm{O}^{\prime} \mathrm{Brien}(2001)$ 참조.
} 
둘째, 재정적인 측면에서의 우호적 환경과 첨단산업의 기반정도와 입지선정시 One-stop 서비스 제공 여부, 외국인 투자에 적절한 유인정책 제공정도, 공항, 항만, 기타 인프라 시설 등 충분한 기반시설의 존재 여부, 인적자원개발 프로그램에 대한 지원여부, 첨단산업 연구 · 개발기관의 집적정도 등이다.

〈표 7) 외국인 투자입지의 결정요인 종합

\begin{tabular}{|c|c|}
\hline 구 분 & 주요 투자입지 결정요인 \\
\hline 투자정책 요인 & $\begin{array}{l}\text { - 경제적 정치적 사회적 안정성 } \\
\text { - 외국인 투자에 대한 법적 · 제도적 일관성 및 국제성 } \\
\text { - 무역 및 조세정책에서의 상대적 혜택 및 일관성 }\end{array}$ \\
\hline 경제적 요인 & $\begin{array}{l}\text { - 배후시장규모 및 성장추이 } \\
\text { - 배후지역시장에의 접근성 } \\
\text { - 교통 · 물류기반 시설의 효율성: 인프라의 구축정도, 양질의 저렴한 용지공급정도 } \\
\text { - 자본 및 생산요소 비용: 질높은 전문인력의 공급정도, 노동비용, 조세혜택의 정도 }\end{array}$ \\
\hline 기업활동 환경요인 & $\begin{array}{l}\text { - 노동시장의 안정성 } \\
\text { - 외국인 거주 및 생활환경: 이민제도, 의료, 교육, 여가생활 }\end{array}$ \\
\hline 행정적 요인 & $\begin{array}{l}\text { - one-stop service의 제공유무 } \\
\text { - 물류행정체계(무역, 통관 등)의 편리성 }\end{array}$ \\
\hline
\end{tabular}

이상과 같은 외국인 투자입지 결정요인들을 통합하면, 물류중심지화의 추진을 위한 조건, 중심지화 전 략의 수립/실천을 위한 모델을 설정해 볼 수 있다. 즉, 외국인 투자입지결정의 통합요소는 다음과 같이 정 리할 수 있다.

- 안정성: 정치 - 사회적 안정성 및 일관성

- 시장성: 배후시장의 규모 및 접근성

- 인프라: 양질의 인프라 구축정도(용지포함)

- 노동유연성: 노동시장의 안정성 및 유연성, 양질의 노동력

- 조세혜택: 조세혜택의 정도

- 환경쾌적성: 외국인 거주 · 생활 환경

- 행정효율성: 행정서비스의 효율성

이러한 외국인 투자입지결정 통합요소를 효율적으로 구축한 국가의 경우 물류중심지화 전략 또는 외 국인투자(FDI)지향형 성장전략을 성공적으로 달성하고 있다.

나. 물류중심지화 전략의 대안모델 설정

앞서 제시한 외국인투자입지 결정 통합요소를 어떠한 방식으로 구축하는가를 기준으로 물류중심지화 전략의 대안모델은 다음과 같이 2 개의 모델로 크게 구분할 수 있다.첫째로는 네덜란드 모형이다. 네덜란드 모형은 네덜란드, 대만, 아일랜드 등이 채택하여 추진하고 있는 모형이다. 둘째로 경제특구 모형을 들 수 있는데, 중국이 채택하여 추진하고 있는 모형이다. ${ }^{8)}$

\footnotetext{
s 각 국이 추구하는 물류중심지화 또는 외국인투자유치 전략의 사례는 하헌구(2002) 참조.
} 
네덜란드 모형과 경제특구모형의 공통점과 차이점을 보면, 공통점으로는 외국인 투자를 유치하기 위 하여 외국인투자입지결정 통합요소들을 효율적으로 확보하고, 자유무역지대, 보세구역 등 조세 특혜를 부 여하는 별도의 지구 설정하고 있다는 점이고, 차이점으로는 외국인 투자입지결정 통합요소들을 달성하기 위한 방안으로 기존 국가시스템과 다른 별도의 지역 구분을 하느냐 하지 않느냐이다.

〈표 8〉 물류중심지화 전략 실천방안

\begin{tabular}{|c|c|c|}
\hline 통합요소 & 네덜란드 모델 & 경제특구 모델 \\
\hline 안정성 & - 사회전체의 안정성 확보 & - 특구에서의 안정성 확보 주력 \\
\hline 시장성 & $\begin{array}{l}\text { - 배후시장에서의 중심성 확보 } \\
\text { - 배후시장과의 연계교통망 확보 }\end{array}$ & $\begin{array}{l}\text { - 배후시장을 고려하여 경제특구 } \\
\text { 입지 결정 }\end{array}$ \\
\hline 인프라 & - 국가적인 효율적인 인프라 구축 & - 경제특구에 대한 인프라 구축 \\
\hline 노동유연성 & $\begin{array}{l}\text { - 노사정간의 대화로 해결 (Social } \\
\text { partnership, Polder model 등) }\end{array}$ & - 노동관계법의 적용배제 \\
\hline 조세혜택 & $\begin{array}{l}\text { - 경제전체적인 낮은 조세 } \\
\text { - 조세특례구역 지정 }\end{array}$ & - 조세구조 차별화 \\
\hline 환경쾌적성 & - 국가전체가 서구화된 생활환경 & $\begin{array}{l}\text { - 외국인 전용주거단지 조성 } \\
\text { - 특구내의 생활환경 서구화 }\end{array}$ \\
\hline 행정효율성 & - 중앙정부 주도의 행정기구 설립 & - 특구를 위한 특별행정기구 설립 \\
\hline
\end{tabular}

\section{(2) 대안 모델의 특성 및 장단점 분석}

네덜란드 모델의 경우 경제전체를 전면적으로 개방하여 사회전체를 업그레이드하는 방식이고, 이에 비하 여 경제특구 모텔은 특정지역만을 개방하여 일부지역만 업그레이드하는 방식이라고 할 수 있다. 어떤 대안모 델을 채택하는가는 각 국가가 처한 지리적, 경제적, 사회적 여건에 따라 다르다고 할 수 있다. 네덜란드 모델 과 경제특구 모델은 비교하여 보면, 전면적인 개방(네덜란드 모델)이 궁극적인 목표이나 경제특구 방식의 개 발은 추진 방법론상의 선택이라고 이해될 수 있다. 즉, 네덜란드모델을 추구하는 과정에서 추진의 용이성을 위하여 단기적으로 경제특구 모델을 선택 - 시행하고 이로부터 궁극적인 Spill-over effect를 기대하는 것이 라고 할 수 있다.그러므로 경제특구 위주의 개발을 추진하더라도 전면적인 제도 개선 및 개방은 병행할 필요가 있으며 경제특구의 개념도 세제혜택 및 일부 규제완화에 한정된 것이 아니라 보다 광범위한 개념을 택할 필요 가 있다. 즉 전 분야에 대한 규제 개혁 및 비즈니스 환경 개선을 추구하는 개념이 그것이다.

(표 9) 대안모델의 비교

\begin{tabular}{|c|c|c|}
\hline & 장 점 & 단 점 \\
\hline $\begin{array}{l}\text { 네덜란드 } \\
\text { 모 델 }\end{array}$ & $\begin{array}{l}\text { - 궁극적인 목표이며 전면적인 } \\
\text { 업그레이드가 가능 } \\
\text { - 투자 및 자원 배분의 최적화 가능 } \\
\text { - 다양한 투자와 고급인력 등의 유치가능 }\end{array}$ & $\begin{array}{l}\text { - 전면적 제도개선을 위한 합의 도출이 어려움 } \\
\text { - 전국적인 제도 변화를 의미하므로 } \\
\text { 추진이 어려움 }\end{array}$ \\
\hline $\begin{array}{l}\text { 경제특구 } \\
\text { 모 델 }\end{array}$ & $\begin{array}{l}\text { - 비교적 추진이 용이 } \\
\text { - 일종의 Pilot Project가 가능 } \\
\text { - 특구로부터 전국적으로 Spill-over } \\
\text { 효과 기대 가능 }\end{array}$ & $\begin{array}{l}\text { - 경제특구와 기타지역과의 역차별 문제 대두 } \\
\text { - 기존 투자의 특구 이동 문제 } \\
\text { - 특구로 투자지역이 제한적인 관계로 효율적 } \\
\quad \text { 자원 배분의 제약 가능성 } \\
\text { - 게토 논란및 고급인력 등의 유치에 제약 }\end{array}$ \\
\hline
\end{tabular}


(3) 물류중심지화를 위한 최적 대안(적용 방안)

물류중심지화의 효율적 달성을 위해서는 앞서 제시한 두가지 모델의 장점을 채택한 혼합모델을 설정 하고 이를 추진하는 것이 바람직할 것이다. 혼합모델의 설정 방향은 경제특구 모델과 네덜란드 모델의 장 점 흡수하고, 실현가능성을 최대한 확보하고 실천비용의 최소화하여야 한다. 또한 실천과정에서 지역간 과 당경쟁에 의한 비효율 발생가능성을 배제하여야 할 것이다.

이에 따른 최적대안 모델은 두가지 대안모델을 결합한 결합모델이 될 것이다. 먼저 순차적인 결합으로 서 국가전체적인 측면에서 외국인투자유치를 가장 효율적으로 달성할 수 있는 특정지역을 특구로 지정하 고, 이의 성공을 토대로 spill-over 효과 기대하는 것이고, 수요자 중심의 조세특례구역 지정하여 외국인 투자자가 원하는 곳에 대하여 조세특례를 탄력적으로 인정하여 특구로 발전시키는 것이다."

\section{2. 물류중심지화를 위한 한국의 여건 평가}

(1) 최적모델의 적용을 위한 한국의 여건 현황

가. 안정성: 정치 - 사회적 안정성 및 일관성

정치 - 사회적 안정성 및 일관성의 측면에서는 아일랜드, 네덜란드, 싱가폴 등과 비교할 때 상대적으로 우월한 상황이라고는 할 수 없다.

나. 시장성: 배후시장의 규모 및 접근성

배후시장의 규모에는 현재 경쟁대상인 중국과 비교할 때 상대적으로 열악한 상황임은 부인할 수 없다. 네덜란드의 경우 $\mathrm{EU}$ 의 가입 및 지리적 인접성 등으로 유럽전체를 배후시장으로 하고 있으나, 한국의 경우 그렇지 못하다. 동북아 전체를 한국의 배후 시장으로 보면 규모의 거대성과 성장성이 있다고 볼 수 있으 나, 지리적 인접성의 결여(북한의 존재 등), 중국 자체를 배후로 하는 상해 등을 감안할 때 한국의 조건은 불리한 것이다. 이상에서 알 수 있듯이 중국경제의 현재 상황 및 장래전망과 한국의 물류중심지화와는 밀 접한 관계에 있는데, 중국의 현재 물류서비스 수준의 후진성의 측면과 전문가들의 중국경제전망을 고려할 때 위협과 기회요인이 동시에 존재한다고 할 수 있다.

\section{다. 인프라: 양질의 인프라 구축정도(용지포함)}

한국의 인프라 경쟁력 순위를 볼 때 우리나라의 인프라 수준은 아시아에서도 중하위에 위치해 있다고 할 수 있다. 즉, 한국의 인프라 경쟁력 순위 ${ }^{10}$ 는 97년 32위, 2001년 34위(47개국 비교)에 불과한 상황이다.

용지가격측면에서도 한국은 싱가포르, 중국 등에 비하여 불리하다. 그 예로 공장분양가 $(\$ /$ 월 - $\mathrm{m} 2)$ 를 비교하여 보면, 홍콩 368 , 싱가폴 9.28 20.5, 중국 2.0, UAE 2.18 4.09, 한국 110 (1998년 기준)으로 한국이 크게 불리하다는 것을 알게 된다."'

9 네덜란드의 조세특례규모를 외국인투자자와 협상에 의하여 결정하는 사례와 외국인 투자자가 원하는 지역을 보 세구역으로 지정하는 사례를 적용

1010 $\operatorname{IMD}(2001)$ 참조.

i1) 하헌구(2002) 참조. 
그러나 인천국제공항과 부산항 - 광양항등의 교통시설인프라 측면에서는 긍정적인 요소를 발견할 수 있다. 항공운송의 자유화 확대, 초대형항공기(mega carrier)의 출현 등은 거대 항공운송 네트워크 구성을 가능케 하여, 과거의 지점-지점(point-to-point) 체계에서 허브-스포크(hub-and-spoke)체계로 전환되 고 있으며, 인천공항은 역내 경쟁공항에 비하여 시설사용료 수준이 비교적 낮고, 환적작업의 효율성이 높 아 많은 항공사들에 의해 선호되고 있다.

〈표 10〉주요 국제공항별 시설사용료 현황

(단위: 천원, B747, 395톤 기준)

\begin{tabular}{c||c|c|c|c}
\hline 구 분 & 인 천 & 간사이 & 홍 콩 & 창 이 \\
\hline \hline 이착륙료 & 2,192 & 9,815 & 4,679 & 2,838 \\
\hline 공항이용료 & 15 & 29 & 8 & 11 \\
\hline
\end{tabular}

자료 : 건설교통부, 내부자료.

이러한 여건에서 우리나라가 지역의 중심성과 접근성을 최대한 활용할 경우 중국시장 등 배후지역에 거주하는 대규모 시장은 커다란 기회가 될 것이며, 장기적으로 동북아 종합교통망 구축의 적지가 될 것이 다. 즉, 우리나라를 중심으로 $2,000 \mathrm{~km}$ 이내에 동북아 주요 대도시가 위치에 있어, 배후지역의 인구가 약 14 억명으로 싱가포르의 3 억 5 천만명과 유럽의 최대 물류거점인 네덜란드의 3 억7천명의 약 4 배 수준인 것이다.

그리고 우리나라(부산, 광양)는 세계 주요 간선항로(Main Trunk Route)상에 위치하여 입지상 유리 하다. 주간선항로(MTR)는 유럽-싱가폴-홍콩-카오슝-부산(광양)-고베-북미 등 인데, 상해는 간선항로 와 이격되어 일본지역 환적화물 처리에는 불리하며, 고베는 간선항로상에 있으나 중국 북부지역화물처리 에는 부적합한 상황이다.

최근 북중국과 일본의 화물을 중심으로 환적물동량이 크게 증가. 동북아 중심항만으로의 성장가능성 을 뒷받침하고 있다. 즉, 출발지 포함시, 중국 환적물량은 전체 환적물량의 약 $60 \%$ 수준(추정)을 보이고 있 다.

〈표 11〉 환적화물 처리추이

(종착기준, 천 TEU)

\begin{tabular}{c||c|c|c|c}
\hline 구 분 & '95 & '98 & $2000(\%)$ & 연평균증가율(\%)('95 2000) \\
\hline \hline 계(\%) & 860 & 1,268 & $2,454(100)$ & $23.3 \%$ \\
\hline 중국 & 234 & 340 & $678(27.6)$ & $23.7 \%$ \\
\hline 일 본 & 98 & 165 & $356(14.5)$ & $29.4 \%$ \\
\hline 기타 & 528 & 763 & $1,420(57.9)$ & $21.9 \%$ \\
\hline
\end{tabular}

자료 : 해양수산부, 내부자료.

향후 TSR, TCR등 대륙철도이용이 활성화될 경우 동북3성, 몽고 - 러시아 - 중앙아시아 - 유럽 및 일본 까지 우리 항만의 배후권역화가 가능하여 부산 - 광양항이 유라시아 관문항으로 발전할 가능성이 크다. 
라. 노동유연성: 노동시장의 안정성 및 유연성, 양질의 노동력

노동시장의 안정성 및 유연성 측면에서 우리나라는 불리한 입장에 있다. 네덜란드의 폴더모델(Polder model), 아일랜드의 사회적 파트너쉽(Social partnership) ${ }^{12}$ 에 의한 노사관계의 안정성 및 노동시장의 유 연성(파트타임의 일반화 등)에 비하면 한국은 크게 불리하다. 노동비용의 측면에서도 한국은 중국 등에 비 하여 불리한 위치에 있다. 일반노동자 임금( $\$$ 월)을 살펴보면, 홍콩 $843 \sim 1,822$, 싱가폴 976 , 중국 100 , 한국 730 1,388(1998년 기준)이며, 엔지니어 임금( $\$$ /월)은 홍콩 $1,610 ~ 3,837$, 싱가폴 1,987 , 중국 200 , 한국 1,066 1,679(1998년 기준)이다.

국민들의 외국어 사용능력에 있어서 한국은 언어소통 능력이 상대적/절대적으로 열위에 있다고 할 수 있다. 홍콩은 영어와 광동어가 법적 언어이고, 싱가폴은 국민의 $95 \%$ 가 영어를 사용하고, 영어생활자가 $45 \%$ 이며, 중국의 언어소통능력은 보통이상으로 평가되고 있다. 전문인력 공급능력의 측면에서는 한국은 교육의지가 높고 학력수준이 상대적으로 높으나, 물류, 국제운송, 국제비즈니스 등 전문분야 담당인력이 상대적으로 부족하다.

마. 조세혜택: 조세혜택의 정도

한국의 조세혜택 정도는 외국인투자촉진법에 따라 상당히 개선되었으나, 물류중심지화를 위한 물류기 업의 유치에는 불리하다. 즉, 외국인투자촉진법 상의 조세혜택 대상업종에서 물류부문은 배제되고 있는 상 황인 것이다. 또한 외국인 투자자의 투자인센티브 매력정도에서 한국은 25 위로 대만 23 위, 싱가폴 2 위, 중 국 16 위 보다 크게 뒤떨어지고 있다. ${ }^{13}$

바. 환경쾌적성: 외국인 거주 · 생활 환경

한국도 점차 서구화된 생활환경을 구축해 가고 있는 것으로 평가되나, 아직 거주 생활환경 측면에서는 홍콩, 싱가포르 등에 비하여 불리하다고 할 수 있다.

사. 행정효율성: 행정서비스의 효율성

외국인 투자기업 설립시 소요일수를 보면 한국은 아일랜드, 홍콩, 싱가폴 에 비하여 많이 떨어지고 있 다. 외국인 투자기업 설립시 소요일수(일)를 보면, 아일랜드 5 일, 홍콩 9 일, 네덜란드 10 일, 아일랜드 15 일, 싱가폴 21 일, 한국, 일본, 대만, 중국 30 일 등이다.

또한 외국인 투자기업 설립시 받아야 하는 허가의 종류(건수)를 보면 한국은 10 건으로 외국(중국 포 함)에 비하여 여전히 많다. 홍콩, 싱가폴, 영국은 2 건이고, 대만, 일본 3 건이다. ${ }^{11}$

(2) 물류중심지화의 성공 가능성 평가

앞서 살펴본 바와 같이 한국은 외국인투자입지의 7 가지 결정요소의 측면에서 전반적으로 물류선진국 이나 중국, 주변 경쟁국들에 비하여 불리한 여건을 가진 것으로 판단된다. 즉, 한국의 물류중심지화 성공가 능성은 매우 낮은 것으로 볼 수밖에 없다. 그러나 21 세기 한국의 생존전략차원에서 물류중심지화전략의 절실함을 감안하여 동북아의 지리적 중심지로서의 강점, 물류인프라 시설과 다국적 물류기업의 동북아시 아지역본부 유치 가능성 측면에서의 긍정적인 요소를 발견하고 이를 기반으로 불리한 점들을 극복하기 위 한 노력이 필요하다.

\footnotetext{
12) 하헌구(2002) 참조.

13) $\mathrm{IMD}(2001)$ 참조.

14 $\mathrm{WEF}(2001)$ 참조.
} 
이러한 측면에서의 한국이 가지고 있는 동북아물류중심지화를 위한 긍정적 요소는 앞서 제시한 공항 과 항만 등 교통인프라와 동북아의 지리적 요충지라는 이점과 일본과 중국간의 기술격차를 메울 수 있는 중급기술을 보유하고 있고, 중국에 비해 숙련되고 일본에 비해 값싼 노동력을 확보하고 있다는 점이다. 아 울러 반도체, 전자 - 전기, 자동차, 철강 등 제조업분야에서 상당한 생산기반을 갖추고 있으며, 일본보다는 떨어지지만 동아시아에서는 상위에 속하는 연구개발투자 및 지적기반을 보유하고 있다.

한 - 일 자유무역협정, 한 · 중 - 일 시장통합의 움직임 등 동북아지역 경제협력의 진전에 따른 반사이 익이 증대되고 있고, 세계기업의 입장에서 보면 통합된 동북아시장은 지역내 거래비용의 감소를 의미하므 로, 지역본부 강화의 인센티브로 작용하여 한국의 지역생산 · 운영본부 유치 가능성이 증대되고 있다고 볼 수 있다. 아울러 남북한의 화해 - 협력의 진전에 따라 한반도의 정치적 위험이 감소하는 동시에 육로를 통 한 대륙접근이 가능해 지면 한국의 입지 매력은 더욱 증대될 것이다.

이러한 여러 가지 요소를 포함하여 동북아물류중심지화를 위한 한국의 강점과 약점은 다음의 표와 같 이 나타낼 수 있을 것이다.

(표 12) 한국의 강점과 약점 분석(SWOT분석)

\begin{tabular}{|c|c|}
\hline 강 점(Strengths) & 약 점(Weakness) \\
\hline 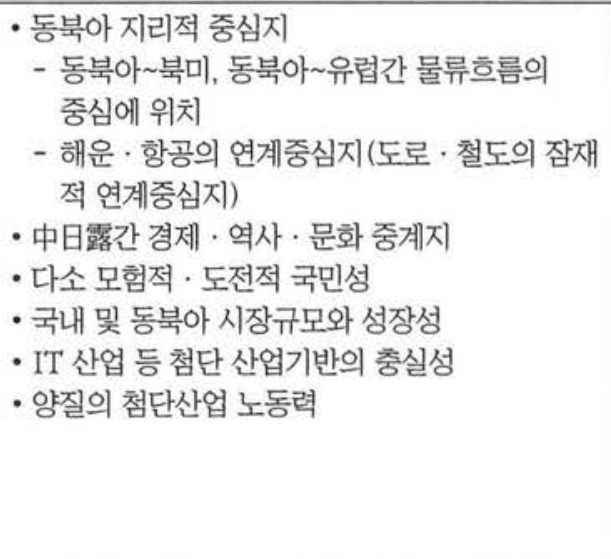 & $\begin{array}{l}\text { • 열악한 기업활동 환경 } \\
\text { - 높은 용지가격 } \\
\text { - 노사관계의 안정성 부족 } \\
\text { - 노동시장의 유연성 부족 } \\
\text { - 복수언어능력의 부족 } \\
\text { - 행정규제 및 절차의 복잡성 } \\
\text { - 정부의 적극적인 행정지원노력 부족 } \\
\text { - 제조업 중심 정책마인드로 물류·비즈니스 } \\
\text { 마인드 미비 } \\
\text { •물류 전문인력 부족 } \\
\text { - 외국인에 불리한 생활환경 } \\
\text { - 상대적으로 높은 세금 등 } \\
\text { • 북한리스크 상존 }\end{array}$ \\
\hline 기회요인(Opportunities) & 위협요인(Threats) \\
\hline $\begin{array}{l}\text { ·동북아경제권 대두 } \\
\text { · 중국의 성장 및 개방(WTO 가입) } \\
\text { - 세계자본의 투자 대상지 } \\
\text { - 지역적 생산 및 소비 기지 } \\
\text { - 비즈니스 및 물류 수요 급팽창 } \\
\text { • 북한리스크 다소 감소 }\end{array}$ & $\begin{array}{l}\text { - 치열한 물류Hub 유치 경쟁 } \\
\text { - 중국, 대만, 일본 등 } \\
\text { - 중국경제의 급부상 }\end{array}$ \\
\hline
\end{tabular}




\section{3. 물류중심지화 추진 전략}

(1) 전략 실천의 기본 방향

물류중심지화 전략을 추진하기 위해서는 물류중심지화를 위한 모델로서 앞서 설정한 "최적대안모델 (결합모델)"을 선택하고 이의 효율적 실천을 위해 노력하며, “최적대안모델"의 효율적 적용 방안은 대상물 품, 부문 등 다양한 측면에서 선택과 집중의 전략이 필요하다. 이러한 선택과 집중전략의 수행방향은 다음 과 같다.

(1) 산업부문간 집중: 비즈니스 중심지화 전략 중 물류중심지화 전략 우선 추진

(2) 대상물품에 대한 집중: 경박단소의 고부가가치 첨단산업제품에 대한 집중

(3) 지역적 집중: 최적의 지점 선택하여 집중육성 후 타지역으로 확산 전략

최적대안모텔의 적용방안으로서는 투자유치에 가장 효율적인 지역을 "경제특구" ${ }^{15}$ 로 지정하고, 외국 인투자입지결정 통합요소(7가지) 충족 및 충족 가능성을 고려하여 상대적으로 배후시장의 규모, 성장 가능 성, 인프라 수준 등의 충족 정도에서 우월한 수도권 지역을 선택한다. 여기에 설치되는 “경제특구”는 충족 된 통합요소를 더욱 강화하고, 미충족 요소를 충족시키기 위한 새로운 패러다임을 도입한다.

아울러 외국기업이 요구하는 지역에 “경제특구"의 특례를 부여하고, 특례의 수준 및 종류는 협상을 통 해 결정하는 탄력적 정책이 필요하다. 이때 기 진출 외국기업의 "경제특구"로의 이동 인센티브는 최소화 한다. 이러한 선택과 집중의 전략과 더불어 외국인투자입지결정요소상의 우리의 약점을 집중적으로 보완 하는 전략의 실천이 중요하다.

[그립 2] 동북아 물류중심지 개념도

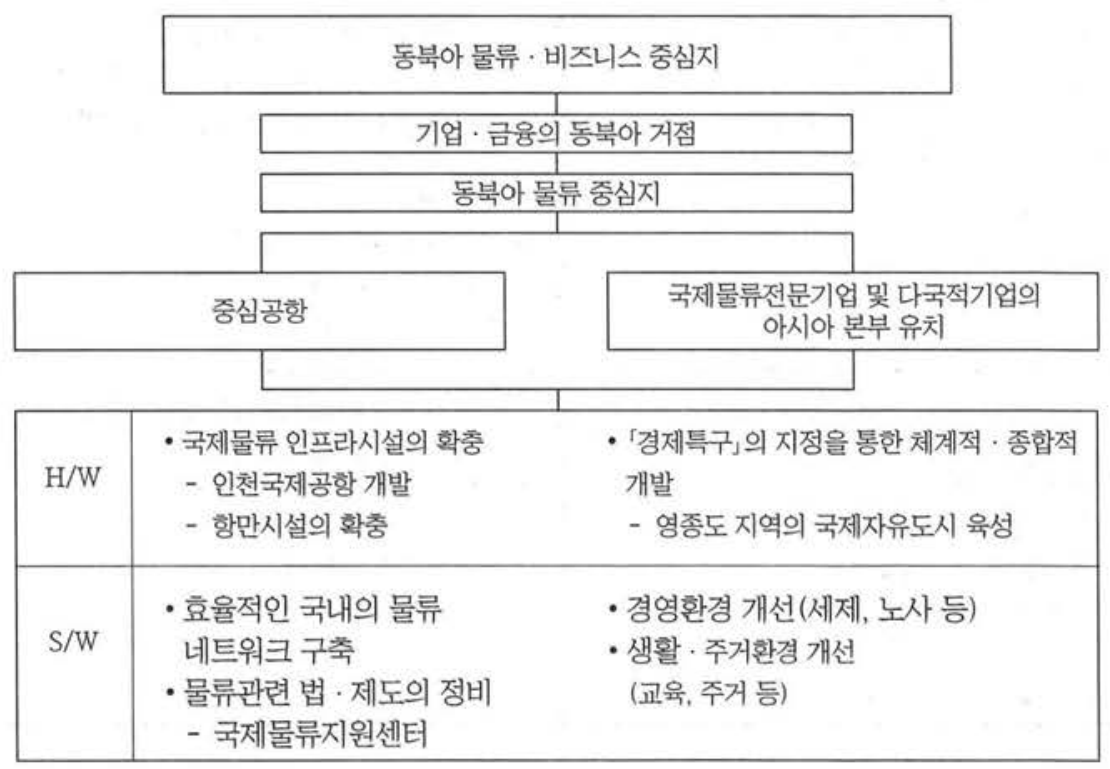

15) "경제특구"라는 용어는 특징을 분명하게 드러나도록 하기위해 사용한 단어이고, 우리나라에서는 관련법률의 제 정과정에서 "경제자유구역"으로 현실화되었음. 
(2) 선택과 집중전략의 수행 방향

가. 특정 산업부문에의 집중과 대상 물품에 대한 집중

관광, 물류, 금융 등 비즈니스 전반적인 부문에서 우리나라가 동북아지역에서의 중심지가 되는 것은 장 기적인 목표로는 당연한 것이나, 모든 분야에서 동시에 목표를 달성하기에는 역량이 분산되기 때문에 우선 적으로 실현가능성이 높은 부문, 즉 물류부문에서의 노력에 집중하고 그 효과를 다른 부문에 확산시키는 전략이 현실적인 대안이 될 것이다.

우선적으로 세계적인 다국적 기업들의 동북아 지역 물류센터를 유치하는 노력을 하고, 이에 대한 성공 을 바탕으로 콜센터, 지역본부 및 연구개발센터를 유치하도록 하는 방안이 현실적이고 성공가능성이 높다 고 할 수 있다. 네덜란드나 싱가포르 등 선진성공사례의 경우 다국적기업들이 지역물류센터를 설치한 후 동일지역에 콜센터, 지역본부 및 연구개발센터를 설치한 사례로 볼 때, 우리나라도 물류중심지로서 성공하 게 되면 자연스럽게 비즈니스중심지로 발전하게 될 가능성이 높다고 볼 수 있다. 즉, 네덜란드에 입지한 45 개 유럽물류센터에 대한 조사결과 $18 \%$ 가 비즈니스 본부와 아울러 고객관계관리 등을 위한 call center를, $16 \%$ 가 call center를, $9 \%$ 가 생산기지 및 call center를 각각 순차적으로 설립. 반면 생산기지나 비즈니스 본부를 먼저 설립한 후 물류센터를 설립한 경우는 $17 \%$ 에 불과하였던 것이다. ${ }^{16}$

물류센터의 주대상은 수도권의 경우 인천공항의 이점을 최대한 살릴 수 있는 고부가가치의 첨단산업 을 대상으로 하는 부가가치 물류활동이 되어야 할 것이다. 고부가가치의 첨단화물의 경우 현재 세계물류 네트웍의 가장 중요한 화두인 적기수송(JIT, just-in-time)과 지연생산(Postponed manufacturing)에 가장 적합하고, 이는 최근 가치면에서의 비중이 급격하게 증가하고 있는 항공물류가 중심이 되고 있기 때 문이다. 우리나라 항공화물의 경우 환적화물의 비중 $(97$ 년도 총항공화물의 $62.7 \%$ 가 환적화물)이 높아서 물류허브로서의 가능성을 시사하고 있다.

전세계 항공화물수요는 향후 20년동안 매년 $6.4 \%$ 증가할 것으로 예상하고 있으며, 아시아 역내 항공화 물증가율은 $8.6 \%$ 로 가장 높을 것으로 예상하고 있다. 그리고 국제화물 중 항공화물의 비중은 물량기준으 로 $0.3 \%$ 이나 가치기준으로는 $30 \%$ 에 이르며, 항공화물수요는 증가세에 있는 것이다.

또한 90 년대 이후 급격히 증대하고 있는 중국발 해-공복합운송(Sea \& Air)의 성장전망을 감안하여 인천항과 인천공항을 연계하는 전략도 필요할 것이다. 중국발 해-공복합화물운송의 경우 92 년에 2 천톤에 서 2010년에는 18만톤으로 급격히 증대될 것으로 예상되고 있다. ${ }^{17}$ 이에 대하여 부산과 광양항은 중후장대 의 중량화물을 대상으로 하는 국제중추항만으로 지속적으로 육성하여야 할 것이다.

나. 지역적 선택과 집중

영종도 및 김포매립지, 송도신도시 등 수도권의 지역이 경제특구로 우선적으로 지정되는 것은 지역의 잠재력과 경쟁력, 장래 발전 가능성으로 볼 때 지극히 타당하다고 할 수 있다. ${ }^{18}$ 앞서 논의한 대로 외국인투 자입지결정 통합요소로서 배후시장의 규모 및 성장속도, 인프라의 구축정도, 양질의 노동력, 외국어 능력 등을 고려하여야 한다. 이러한 요인들을 고려할 때 수도권이 가장 적합하며, 수도권에서도 공항과 항만이 위치한 인천과 그 주변지역이 다국적 기업의 유치에 유리하다.

16 전일수(2002) 참조.

in 하헌구(2002) 참조.

100 2003년 7월에 영종도, 김포매립지, 송도신도시 등이 “경제자유구역"으로 지정된 것은 바람직한 것이라고 할 수 있음. 
현재 수도권 지역은 우리 나라 면적의 $12 \%$ 에 불과하지만 전체 인구의 $46 \%$, 제조업의 $55 \%$, 금융대출 의 $62 \%$, 그리고 지역총생산(GRDP)의 $46 \%$ 가 집중해 있고, 그중에서 서울은 수도권 인구의 $46 \%, \mathrm{GRDP}$ 의 $46 \%$, 고용의 $47 \%$ 정도를 차지하고 있는 현실적인 측면은 중요한 요소이다. 이러한 수도권 개발에서도 우선순위를 분명히 하고 이에 대한 개발전략을 수립, 실천해야 하며, 수도권에서의 세부지역 개발 우선순 위는 인천국제공항과의 연계성, 배후시장의 규모 등 “최적대안모델"의 조건을 감안하여 결정하여야 할 것 이다.

\section{(3) 약점보완 전략의 수행 방향}

“최적대안모델"의 효율적 적용을 위해서는 선택과 집중의 전략 수행과 더불어 외국인 투자유치 입지 결정요소중의 약점으로 지적된 사항들에 대한 집중적인 보완이 필요한데, 이러한 약점의 보완은 경제특구 에 우선적으로 적용할 사항과 경제전체의 업그레이드를 위하여 필요한 사항, 시간적 우선순위 등을 구분하 여 실천하여야 할 것이다.

\section{IV. 동북아물류중심지화 전략의 성공을 위한 추진과제}

앞에서 제시한 동북아물류중심지화 전략 모델을 바탕으로 전략의 성공을 위한 추진과제는 우리나라가 가지고 있는 약점을 보완하는 것이 될 것이다. 약점의 보완은 경제전체적인 규제완화와 개방을 의미하기 때문에, 정책의 집행과정에 대한 이해당사자들의 반발로 인한 부작용이 초래될 수 있다. 따라서 "경제특 구" 즉 "경제자유구역"을 설정하고, 이 지역에서는 약점을 최대로 보완하여 앞서 제시한 모델에서의 조건 을 완전히 충족시키도록 하는 것이 바람직할 것이다. 약점 보완 내지는 모델에서 제시하고 있는 조건을 만 족시키기 위한 추진과제는 다음과

\section{1. 시장접근성 확보}

\section{(1) 자유무역협정(FTA)을 통한 배후시장규모의 확대}

한국은 현재 $\mathrm{OECD}$ 국가중 유일하게 경제블록에 편입되지 못하고, 자유무역협정(FTA)을 체결하지 못한 국가인데, 중국및 일본에 비해 상대적으로 작은 내수시장의 한계극복방안은 자유무역협정이 유일한 해결책인 것이다.

먼저 일본과의 자유무역협정을 우선적으로 추진하고 중국, 미국과도 추진하는 것이 바람직할 것이다. 중국과 미국의 경우 농업분야의 반발이 장애이나, 장기적으로 농업분야에 대한 구조조정 필요한 상황이므 로, 적극적 추진의지가 필요하고, 또한 동남아시아국가들(ASEAN)과도 자유무역협정의 추진이 필요할 것이다.

(2) 동북아 항공 및 해운 네트워크의 구축

동북아 국가들과의 자유무역협정의 체결과 더불어 사람과 화물의 이동성을 향상시키는 것이 중요한 데, 이를 위해서는 항공 및 해운네트워크를 확충하는 것이 필요하다. 인천공항과 중국 및 일본의 항공노선 ${ }^{19}$ 을 중소도시로 더욱 확대하여야 하고, 이와 같이 운항도시 및 운항밀도의 증대를 통하여 항공사허브로 육 성하고 이를 바탕으로 허브공항화 추진하여야 한다.

\footnotetext{
${ }^{17} 2003$ 년말 8 월 현재 인천공항은 중국의 22 개도시, 일본의 24 개 도시와 항공노선으로 연결되어 있음.
} 
이와 더불어 일본 및 중국과의 단계적 항공자유화(Open-sky) 협정을 추진할 필요가 있다. 그리고 중국 및 일본의 중소규모항만과 국내항만과의 해운네트워크 구축하여 환적물량 유치를 추진하여야 할 것이다. 또한 육상운송 네트워크의 구축을 위하여 한반도횡단철도(TKR)를 조기에 개통하도록 하고, 이를 중국횡 단철도(TCR), 만주횡단철도(TMR), 시베리아횡단철도(TSR) 등과 연계하여 동북아 대륙내륙지역과의 물 류네트워크 구축을 추진하는 것이 필요하다.

\section{2. 무역, 통관, 물류 체계 개선을 통한 물류인프라 구축}

무역 통관 등 물류체계의 개선을 다음과 같은 여덟가지의 사항에 대한 규제완화를 추진하는 것이 바람 직할 것이다. 첫째로, 수출입승인의 면제 요건 완화이다. 수출입승인의 면제요건과 관련하여 관세자유지역 이나 자유무역지대 또는 보세구역으로 반출입되는 물품의 요건을 완화할 필요가 있다. 특정거래의 수출 입인정과 관련하여 중계무역, 외국인수수입, 외국인도수출, 무환수출입의 경우에도 금액기준을 현재의 1 만 불에서 보다 상향조정 필요가 있다.

둘째, 외국환 관리 관련규제완화인데, 외국환 관리법상의 각종 규제를 완화하여 외국인 투자와 관련된 장애요인을 제거할 필요가 있다. 먼저, 채권회수의무의 면제로서 1 건당 미화 5 만불을 초과하는 채권에 대 하여 외국인거주자에 대해 회수의무를 폐지할 필요가 있다. 또한 외국환은행의 매각대금의 한도 폐지할 필 요가 있는데, 현재 외국환은행이 외국인거주자에 대한 매각대금의 한도를 외국인거주자가 매각한 한도 내 로 설정하고 있다. 그리고 외국인투자기업의 단기외화자금의 차입한도를 일률적으로 적용하여야 하고, 결 산순이익금의 대외송금시 감사증명서 제출요건을 폐지할 필요가 있다.

셋째, 보세구역의 특허기간 연장 및 보세공장 업종제한 완화이다. 관세법상의 문제점과 개선방안으로 보세구역의 특허기간의 연장과 보세공장에서의 원재료 제한의 완화를 들 수 있다. 보세공장에서의 내국물 품만을 원재료로 하여 제조 - 가공을 할 수 없도록 하고 있으나 외국인투자기업의 경우에는 완화할 필요가 있는 것이다. 또한 현재 보세공장업종을 2 가지로 제한하고 있는 것을 외국인투자에 한정하여 그 제한을 완 화하는 것이 바람직할 것이다.

넷째, 외국인 투자지원 인센티브를 보완하는 것이다. 외국인투자촉진법은 글로벌제조업체의 국내유치 를 목표로 하고 있기 때문에 투자유치지역과 인센티브가 산업단지를 중심으로 이루어져 왔다. 항만 및 배 후단지의 활성화와 외국인투자유치확대를 위해서는 해운/항공 물류기업과 물류기능 강화를 위해 투자하 는 다국적기업에 대한 투자지원 및 인센티브제도가 필요하다.먼저, 외국인투자금액의 우대 하한선을 인하 하고, 투자요건상의 사업지원서비스업과 고도기술수반사업의 지원요건에 지식기반산업인 IT, BT, NT, CT도 포함될 수 있도록 하여야 하며 기술발달이나 신산업을 유연하게 수용할 필요성이 있다. 또한 외국인 투자에 대한 조세지원내용의 불명확하여 개선이 필요하고, 외국인투자지역에 대한 지원문제는 구체적 지 침이 필요한데, 시행령과 시행규칙에 구체적 가이드라인을 제시할 필요가 있다.

그외에도 외국인투자와 관련한 강력한 조직이 필요하므로 외국인투자와 관련한 전문기구를 창설하여 여기에서 외국인투자와 관련한 모든 행정업무와 민원업무를 처리할 필요성이 있다. 즉, 외국인 투자를 위 한 원스톱체제가 미비(지원조직에 대한 미비)한 바, 편리하고 용이하게 투자할 수 있는 절차간소화와 지원 제도가 확립되어야 한다.

다음으로는 종합물류정보시스템의 확충을 통한 물류정보화의 지속 추진이 필요하다. 과다한 물류비는 국가의 대외경쟁력 약화 요인으로 물류 전반의 정보화 추진을 통해 신속하고 저렴한 One-stop 물류서비 스를 제공할 수 있어야 한다. 물류정보화는 물류정보인프라의 구축, 수출입 - 국내화물의 자동화 - 전산화 추진이 주요 대상인데, 종합물류정보망, 항만운영정보시스템(PORT-MIS), 철도운영정보시스템 (KROIS)의 지속적인 추진을 통한 물류정보인프라 구축이 필요하다. 


\section{3. 교육제도의 개선을 통한 물류관련 전문인력 육성 기반 구축}

현재 우리나라 교육의 경쟁력 향상을 위해서는 교육 시장을 대외 개방하여 교육 부문에 시장원리를 도 입하여 경쟁력을 향상토록 하는 것이 필요하다. 대학원 뿐만 아니라 대학교 및 중등 교육기관, 기숙학교 등 외국교육기관의 유치도 추진되어야 하며 우수 외국 교육기관 유치를 위한 용지 시설 등, 적극 지원이 필수 적이다. 우수 외국 교육기관 유치는 우선 Pilot project를 통해 시행착오를 극복하고 성공적으로 정착시킨 후 전면적 제도 개선을 도모하는 것이 바람직하다.

먼저, 영어, 중국어를 비롯한 제 2 외국어 교육 인프라 구축을 위한 예산지원의 확대가 필요하다. 외국 어 담당 교사의 능력 신장을 위한 연수기회 확대 및 회화 중심의 교육 강화의 추진이 필요하다.

둘째로, 외국어 교육 강화를 위한 외국인 교원 임용 꽌련 외국인 보조교사의 신분 안정을 보장하는 내 용으로 관련 규정 보완이 필요하다. 그리고 “경제자유구역"을 중심으로 외국어 특성화 학교의 설립 확대가 필요하며, 국제화된 우수인력의 조기 양성을 위하여 국제 중, 고등학교 설립이 가능해야 한다.

또한 외국 대학(원) 분교 유치를 지원하도록 해야 한다. 이를 위해 수업방식과 교원활용 등의 제한 폐 지 또는 완화가 필요하다. 싱가포르는 아시아에서 외국대학 수입에 가장 적극적으로, 유럽 비즈니스 스쿨 랭킹 1 위인 인시아드(INSEAD)의 분교를 1999년 유치하였고, 미국 시카고대학 경영대학원도 2001년 아시 아 캠퍼스 설립 과정에서 싱가포르정부는 부지 알선, 비용 차입과 재정보증 등 많은 행정지원을 하여 유치 하였다. 이에 비해 우수/비우수 대학(원) 구별없이 무조건 분교 설치를 허용한 일본은 실패한 사례에 속한 다고 할 수 있다. 일본에는 1980 년대 외국 대학(원) 분교가 30 여개에 이르렀으나, 현재 미국 템플대학과 일 리노이대 등 2개 정도만 명맥을 유지하고 있는 실정이다.

\section{4. 조세체계의 개선을 통한 선진 물류기업 유치기반 구축}

동북아 물류중심지화를 위한 외국인직접투자(FDI) 유치를 위하여 우리나라의 법인세율을 추가로 인 하하고 소득세의 누진율을 완화하여 친비즈니스환경을 조성하는 것을 적극 고려하여야 한다. 우리나라는 경쟁력 강화를 위해 2001년 말 세법개정에서 법인세와 소득세의 세율을 인하한 바 있으나 추가적인 조정을 고려할 필요가 있다. ${ }^{21}$

먼저, 세계적 국제물류전문기업 및 다국적 기업의 아-태지역 본부의 국내 유치와 관련, 필요한 건물 및 부동산을 취득하는데 있어서 편의제공 및 세금감면(취득세, 등록세 등) 등 혜택을 부여하는 방안이 필요하 다. 외국 금융기관에 대한 법인세 등 세금감면과 관련하여 주요국 정부가 역외금융센터에 입주한 금융기관 들에 적용하는 기준을 참고, 결정할 필요가 있다.

둘째, 조세혜택에 대하여 일정대상 또는 일정지역(국제자유도시 등)으로 한정하는 것에 대하여 $\mathrm{OECD}$ 의 유해조세감면제도에 대한 규제와 관련하여 일정한 한계는 있으므로 전체적인 조세율 인하에 대 한 검토가 또한 필요하다. 조세지원방안은 조세감면의 대상을 한정하지 않고 우리나라의 법인세 및 소득세 율을 전반적으로 인하하는 방안을 검토할 필요가 있다. 이는 $\mathrm{OECD}$ 의 유해조세제도 지적을 피하면서 물류 및 비즈니스 중심지를 위한 다국적기업의 거점형 투자를 유인할 수 있는 방안이라고 할 수 있다.

m 초/중등교육법 제21조 및 교육공무원법 제32조와 관련되는 사항입.

211 외국인 투자와 관련된 조세관련 법률에는 외국인 투자촉진법(법률 제6460호 재정경제부), 법인세법(법률 제6293 호 재정경제부), 조세특례제한법 (법률 제6519호 재정경제부), 소득세법(법률 제6429호 재정경제부), 국제물류기지 육성 을 위한 관세자유지역의 지정 및 운영에 관한 법률 (법률 제6305호 재정경제부), 자유무역지역의 지정 등에 관한 법률 (법률 제6506호 산업자원부) 등의 법률이 존재한다. 
그리고 “경제자유구역"에 입주하는 외국기업 뿐만 아니라 우리나라에 근무하는 모든 외국인 임직원에 대해 조세감면 적용요건을 완화토록 추진한다.

\section{5. 노동시장의 유연성 및 노사관계의 안정성 확보}

노동시장의 유연성 확보 및 노사관계의 안정성 확보는 우리나라의 동북아물류중심지화는 물론 전반적 인 외국인투자(FDI) 유치와 우리경제의 선진화를 위해서도 가장 중요한 사항이다. 사회안전망의 확충과 함께 노동시장의 유연성 확보가 추진되어야 한다. ${ }^{23}$

노동시장의 유연성 확보와 관련하여 비정규직 근로자 보호와 관련된 가장 큰 쟁점인 기간제근로(즉 계 약직)의 보호와 파견근로자법의 개정이다. 현행 우리나라 법에는 기간제근로에 대한 규제가 없는데, 노동 단체는 외국의 경우처럼 객관적인 이유를 제시하도록 의무화 하고, 계약직으로 3 회 반복하여 고용되거나 2 년 이상 고용시에는 정규직으로 자동 전환을 주장하고 있고, 경영계에서는 현행 1 년인 계약직의 최대 계약 기간을 3 년으로 연장할 것을 주장하고 있다. 이는 정규직의 고용보호 규제완화와 함께 추진하여야 한다. 상 당수의 $\mathrm{OECD}$ 국가에서 파견근로에 대한 규제가 완화되는 추세이며 파견근로에 대해 Positive System에 서 Negative System으로 개정될 필요가 있다.

정규근로자의 고용보호 정도에 있어서 우리나라는 포르투갈 다음으로 고용보호정도가 강한 것으로 알 려져 있으며 계약직의 활용의 용이성에 있어서 우리나라는 OECD국가 중 중간으로 평가되고 있다. 우리나 라는 외환위기 이후 경제적 이유에 의한 정리해고를 합법화하고 정리해고시의 절차를 법에 규정하고 있다. 정규직의 고용보호 완화는 노동 유연성의 확보 차원에서 추진될 필요가 있다.

\section{6. 외국인의 거주, 생활 환경 선진화}

외국인의 거주, 생활 환경의 선진화는 사회전체를 대외 개방도와 적응성이 높은 사회로 개편하는 것이 라 할 수 있다. 특히 중요한 쟁점중의 하나가 되고 있는 의료 서비스에 관하여는 의료 부문을 대외 개방하 여 외국과의 경쟁에 노출시켜 이용자 편의와 경쟁력 향상을 도모할 필요가 있다. ${ }^{23}$

의료서비스와 관련하여 가장 불편한 점으로는 언어소통 문제이다. 응급상황이 발생했을 때 상당수가 외국인들의 민간회원제시스템을 이용하고 있는 것으로 나타났다. 또한 건강 - 환경과 관련 병원 서비스의 개선, 상수도의 수질 개선 및 공기오염 정화 등의 노력이 필요하다.

또한 외국인에 의한 병원 및 약국 설립을 허가하여 외국인들에 대한 병원서비스의 질 향상이 필요하다. 또한 내국인도 이용 가능토록 하여 수익성 보장 및 경쟁력 향상이 필요하다.

그리고, "경제자유구역"에 외국기업에 근무하는 외국인 직원 및 임원들이 거주할 만한 지역을 건설하 는 등 쾌적한 생활환경(외국인 전용 주거단지 등) 제공이 필요하다. 국내에서 생활환경이 가장 양호한 것 으로 평가되는 서울의 경우에도 홍콩이나 싱가포르 등에 크게 뒤지는 것으로 평가되는 점을 감안할 때 서 울 이외 지역의 생활환경은 더욱 뒤질 것으로 예상된다.

${ }^{22}$ 외국인 투자와 관련된 노동관련 법률에는 근로기준법(법률 제 5309 호 노동부), 노동조합및노동관계조정법(법률 제6456호 노동부), 외국인투자족진법(법률 제6460호 재정경제부), 노동위원회법 (법률 제 5962 호 노동부) 등의 법률이 존 재한다.

23) 외국인 투자와 관련 거주, 생활여건관계 법률에는 대표적인 것으로 국민의료보험법(법률 제6124호 보건복지부), 도로교통법(법률 제5914호 건설교통부) 등의 법률이 존재한다. 


\section{V. 맺음 말}

이제까지 여러 가지 측면에서 동북아 물류중심지화의 필요성, 동북아 물류중심지화를 위한 추진모형 을 설정하고 이를 바탕으로 추진과제를 살펴보았다. 동북아 물류중심지화의 성공을 위한 최소한의 요건으 로는 세계적인 다국적 물류기업의 물류센터(Distribution Center)나 지역본부(Head Quarter)를 본 논문 에서 제시하는 전략의 핵심인 “경제자유구역"에 유치하는 것이라 할 수 있다. 이를 위해서는 최적대안모델 의 적용, 선택과 집중, 그리고 지속적인 추진, 약점의 집중적인 보완이 필요한 것이다.

이처럽 세계적인 물류전문기업의 국내유치를 위한 최소한의 조건을 갖추는 것이 "경제자유구역" 즉 동북아 물류중심지화 전략 성공을 위한 필요조건이라 할 수 있으며, 세계적 물류전문기업의 유치 여부는 중국과의 유치경쟁에서의 승리가 관건이라 할 수 있다. 즉, 중국보다 저렴한 임대료의 풍부한 용지를 공급 할 수 있어야 하며, 착륙료 등 공항이용료의 경쟁력을 유지하고, 노사관계를 안정시키며, 조세혜택 수준을 극대화하면서, 동북아 최고수준의 기업활동 및 외국인 생활환경을 조성하는 것이 필요하다.

이러한 세계적 물류전문기업의 유치를 레버리지로 다양한 기업들의 외국인직접투자(FDI)를 유치함으 로써 경제자유구역은 동북아 물류중심지로 성장할 수 있을 것이다. 나아가 국제자유도시의 물류중심지화 의 파생적인 결과로 비즈니스 등 다양한 경제활동의 복합중심지로 발전할 수 있고, 이는 동북아아시아 국 가들 특히 중국이 창출하는 부가가치를 흡수함으로써, 물류분야는 제조업을 대체하는 새로운 성장엔진으 로서의 역할을 할 수 있을 것이다.

\section{참 고문헌}

김준동(1997), 『FDI유치의 장애요소와 활성화방안』, 대외경제정책연구원

전일수(2003. 8), 「21세기 동북아 물류중심지화 실천전략」, 동북아경제포럽· 교통개발연구원

공동컨퍼런스 발표 자료집

하헌구(2002) 외 편, 『동북아물류중심지화 전략 수립 및 시행방안』, 교통개발연구원 · 동북아경제포럼

하헌구(2002) 외 편, 『동북아 물류중심지화를 위한 여건분석 및 추진전략』, 교통개발연구원 · 동북아경제포럼 하헌구(2003. 9), 「세계 최고수준의 물류산업클러스터를 조성하기 위한 물류기반시설 확충과 법 - 제도

정비의 실천방안」『동북아 물류중심지 발전전략: 순차적 실천방안 및 실행체계 구축』, 동북아경제포

럼 한국위원회 · $\mathrm{IBC}$ 포럼

Booz-Allen \& Hamilton (1997) Revitalizing the Korean Economy Toward the 21th

Century.

Brush, T. H., C. Martin and A. Karnani (1999) "The Plant Location Decision in

Multinational Manufacturing Firms: An Empirical Analysis of International

Business and Manufacturing Strategy Perspectives," Production and Operations Management, Vol. 8, No. 2, Summer . pp. 109-131.

International Institute for Management Development(IMD) (2001) The World

Competitiveness Yearbook 2000.

Jun, Il-Soo ed. (2001) Building Northeast Asian Logistics Centers in Korea, The

Korea Transport Institute and Northeast Asia Economic Forum.

Ha, Hun-Koo et. als ed. (2002) Comprehensive Study on Building a Regional

Distribution and Logistics Hub in Korea, The Korea Transport Institute and

Northeast Asia Economic Forum. 
O' Brien, Phil (2001) “The Role of Distribution and Logistics Centers on the New

Global Auto Route," paper presented at 22nd World Ports Conference of the IAPH, Montreal, May 19-26.

UNCTAD $(1998,999)$ World Investment Report, UN. 